\title{
Sivil Toplum Kuruluşlarında Finansal Şeffaflık: Türkiye ve ABD Uygulamalarının Karşılaştırmalı Analizi*
} (Araştırma Makalesi)

Financial Transparency in Nonprofit Organizations: The Comparative Analysis of Turkish and US Practices

Doi: 10.29023/alanyaakademik.658182

Mehmet Fatih GÜNER

Doç. Dr., Alanya Alaaddin Keykubat Üniversitesi İ̈BF Işletme Bölümü

fatihguner01@gmail.com

Orcid No: : 0000-0002-1388-8681

Bu makaleye atıfta bulunmak için: Güner, M.F. (2020). Sivil Toplum Kuruluşlarında Finansal Şeffaflk: Türkiye ve ABD Uygulamalarının Karşılaştırmalı Analizi. Alanya Akademik Bakış, 4(1), Sayfa No. 39-51.

\section{Anahtar kelimeler:}

Sivil Toplum

Kuruluşları,

Hesap Verebilirlik,

Finansal Şeffaflik,

Form 990

Makale Geliș Tarihi:

11.12.2019

Kabul Tarihi:

22.01.2020

Keywords:

Nonprofit

Organizations,

Accountability,

Financial

Transparency,

Form 990

JEL Classification Codes: M14, M48, H83

\begin{abstract}
ÖZET
$\overline{\text { Iyi yönetişim, sürdürülebilir finansman ve toplumsal destek Sivil Toplum }}$ Kuruluşlarının (STK) varlıklarını devam ettirebilmeleri açısından çok önemlidir. Başarll STK'lar faaliyetleri ve finansal durumları hakkında paydaşlarını bilgilendirmekte, bir anlamda paydaşlarına hesap vererek sürdürülebilir başartyı gerçekleştirmektedirler. Bu araştırmanın amacı STK'lardaki hesap verebilirliğin neden gerekli olduğunu kuramsal açıdan ortaya koyarak hesap verebilirlik bağlaminda Türkiye ve $A B D$ uygulamalarını karşılaştırmalı olarak incelemektir. Bu çerçevede iki ülkenin mevzuatı karşılaş̧ırılmış, özellikle ABD'deki Form 990 uygulamasının Türkiye'deki beyannamelerden farkı araştırılmıştır. ABD'deki hesap verebilirlik uygulamalarının Türkiye'deki uygulamalara klyasla daha kapsamlı finansal bilgiler sunduğu ve bu bilgilerin kamuoyuna daha açık olduğu sonucuna ulaşılmıştır.
\end{abstract}

\begin{abstract}
Good governance, sustainable finance and public support are essential for Nonprofit Organizations (NPOs) in order to exist. Successful NPOs perform sustainable success by providing information to stakeholders, in other words accountability to stakeholders. The aim of this study is to compare Turkish and US practices in the context of accountability by presenting why accountability is necessary for NPOs. In this context, the legislation of the two countries has been compared and the Form 990 in the USA has been reviewed and the differences between the Turkish forms and Form 990 have been revealed. It has been concluded that accountability practices of NPOs in U.S. provides more comprehensive financial information than their Turkish counterparts; and in the US, more stakeholders have access to it.
\end{abstract}

\footnotetext{
* Bu araştırma, 18-20 Nisan 2019 tarihinde Alanya'da düzenlenen 6. Uluslararası Sosyal, Beşeri ve İdari Bilimler Sempozyumunda bildiri olarak sunulmuştur.
} 


\section{GIRISş}

Sivil Toplum Kuruluşları (STK) çok eski tarihlerden günümüze sosyal, siyasal ve ekonomik düzenin önemli bir aktörü olarak faaliyet göstermektedir. Önceleri daha çok gönüllülük ilkesi çerçevesinde ve ulusal sınırlar içerisinde yürütülen sivil toplum faaliyetleri, göreceli olarak küçük örgütler/kurumlar tarafından gerçekleştirilmekteydi. Küreselleşme, bilişim ve iletişim teknolojileri gibi temel etkenler toplumsal gelişim, kamu yönetimi reformları, siyaset sosyolojisi ve demokratikleşme gibi unsurlar ile sivil toplum kavramını ve uygulamalarını da etkilemektedir. $\mathrm{Bu}$ etkileşim sivil toplum alanında faaliyet gösteren kurumları çeşitlilik, sosyolojik rol ve ekonomik büyüklük bağlamında önemli ölçüde zenginleştirmiştir. STK'lar küçük yerel derneklerden çok geniş ve oldukça profesyonel kuruluşlara (Şahin ve Öztürk, 2008:15) farklı alanlarda çalışan gönüllü örgütlerden düşünce kuruluşlarına, sosyal hareketlerden vatandaşlık girişimlerine, hükümet-dışı örgütlerden sendikalara ve meslek odalarına kadar geniş bir yelpaze içinde hareket etmektedirler (Keyman, 2006:10).

Günümüzde vakıf, dernek, meslek örgütü, sendika, siyasi parti çatısı altında on binlerce sivil toplum hareketi faaliyet göstermektedir. Devasa bir büyüklüğe ulaşan sivil toplum dünyasının düzenli çalışabilmesi için bu alanda yasaların ya da standartların belirlenmesi gerekmektedir. $\mathrm{Bu}$ çerçevede STK'ların kuruluş, örgütlenme, finansman, faaliyetlerin yürütülmesi ve kontrolü gibi başlıklarda çeşitli yasal düzenlemelere konu olduğu görülmektedir. STK'larda hesap verebilirlik olarak da tanımlanan STK'ların faaliyetleri ve faaliyetlerinin finansal sonuçları hakkında paydaşlarını bilgilendirmeleri de yasalarla düzenlenen konulardan biri olarak karşımıza çıkmaktadır. Konusu sadece STK'larda hesap verebilirlik ile sınırlı olan bu araştırmanın iki temel amacı bulunmaktadır:

1. Hesap verebilirlik kavramı çerçevesinde STK'ların neden kamuoyunu bilgilendirmeleri gerektiğini kuramsal açıdan ele alarak Türkiye'deki durumu ortaya koymaktır.

2. Türkiye ve ABD'deki hesap verebilirlik mevzuatını karşılaştırmak, özellikle ABD'de başarılı bir şekilde uygulanan STK'ların kamuoyunu tatmin edici bir şekilde bilgilendirmelerini sağlayan etkili bir araç olan Form 990 uygulaması hakkında bilgi vermek ve bu uygulamanın Türkiye'de uygulanabilirliğini araştırmaktır.

Bu bağlamda ilk olarak hesap verebilirlik kavramı vekâlet kuramı ve paydaş kuramı açısından değerlendirilerek STK'ları hesap verebilirliğe zorlayan etkenler açıklanmaktadır. Sonra Türkiye'de STK'larda hesap verebilirlik hakkındaki mevzuat incelenmektedir. Daha sonra ABD'de kullanılan Form 990 isimli beyanname detaylı bir şekilde ele alınmaktadır. Son olarak değerlendirme ve öneriler başlığı altında Türkiye ve ABD hesap verebilirlik uygulamaları karşılaştırılmaktadır.

\section{STK'LARDA HESAP VEREBİLİRLİK: KAVRAMSAL ÇERÇEVE}

Hesap verebilirlik bir kişi ya da kurumun yürüttüğü faaliyetleri ve bunların sonuçlarını ilgi duyanlara ve yasal mercilere bildirme yükümlülüğü olarak tanımlanmaktadır (Yuesti vd., 2016). Başlangıçta sadece sivil toplum yazınında kullanılan ve STK'ların uygulamaya çalıştığı hesap verebilirlik kavramı zamanla işletme yönetimi ve kamu yönetimi yazınında da sıklıkla kullanılır olmuştur (Lee, 2004). Lloyd (2005:3) hesap verebilirlik kavramının geleneksel olarak "vekâlet kuramı" kapsamında değerlendirildiğini, bunun özel işletmeler için doğru olabileceğini ama STK'larda hesap verebilirliği "paydaş kuramı” kapsamında 
değerlendirmenin daha doğru olacağını ifade etmektedir. Vekâlet kuramı mülkiyeti elinde bulunduran pay sahipleri (asıllar) ile başka bireyler (vekiller) arasında, bazı karar verme yetkilerini de içeren yönetim hizmetlerini yerine getirmesi amacıyla bir sözleşme geliştirilmesidir (Mirze ve Ülgen, 2013:465). Vekâlet kuramına göre vekilin, asılı faaliyetler ve faaliyet sonuçları hakkında bilgilendirmesi gerekmektedir. Çünkü vekil yönetim eyleminden sorumlu olan kişi olarak asıldan işletme ile ilgili olarak daha fazla bilgiye sahip olabilmektedir (Çelik ve Bedük, 2014). Bunu sağlamak için yasal teşvikler ve yaptırımlar bulunmaktadır. Vekâlet kuramının STK'lara uyarlanması durumunda bağışçılar, devlet ve söz konusu STK'nın yönetim kurulu gibi birimler bilgilendirilirken STK'ların sunduğu hizmetlerin kullanıcıları ihmal edilebilmektedir. Bundan ötürü "vekâlet kuramı" yerine “paydaş kuramı” STK'larda hesap verebilirlik açısından daha faydalıdır (Lloyd, 2005:3).

Paydaş kuramı, bir işletmenin/kuruluşun varlığını devam ettirebilmesi için paydaşların beklentilerini karşılaması gerektiğini ileri süren bir yaklaşımdır. Ertuğrul'a göre (2008:207) paydaş kavramı dar tanımıyla kuruma doğrudan ekonomik fayda sağlayan grupları; geniş tanımıla kurumun faaliyetlerinden etkilenen ya da faaliyetleri etkileyen herkesi kapsamaktadır. Geniş tanımın içerisine insanlar arasındaki ilişkilerin yanısıra insan ve çevre ilişkisi de dahil edilebilir (Yuesti vd., 2016). Kuruluşun başarısının kuruluşun amacının gerçekleşmesini etkileyebilecek müşteriler, çalışanlar, tedarikçiler, ortaklıklar, finans sağlayanlar ve diğer ana (hedef) kitleleri ile olan ilişkilerini nasıl yönettiğine bağlı olduğu fikrine dayanan (Çınarlı, 2014) paydaş kuramı hangi paydaş gruplarının yönetimin ilgisini gerektirdiğini ve bu ilgiyi hak ettiğini sistematik bir şekilde belirlemeye yardımcı olmaktadır. $\mathrm{Bu}$ sistematik süreç kurum kaynaklarının gereksiz faaliyetlere ve düşük önem derecesine sahip paydaşlara yöneltilmesine engel olarak yöneticilere destek sağlamaktadır (Ertuğrul, 2008:205).

Paydaş kuramına göre STK'larda hesap verebilirliği dört farklı grupta sınıflandırmak mümkündür (Lee, 2004). Birincisi STK'ların kendilerine finansal destek ve yasal çalışma ortamı sağlayan bireysel bağışçılara, kurumsal bağışçılara ve devlete hesap vermeleridir. İkincisi STK'ların sunduğu hizmetlerden ve olanaklardan faydalanan kullanıcılara hesap vermeleridir. Üçüncüsü STK'ların kendileridir. Misyon, değerler, çalışanlar ve yöneticileri göz önünde bulundurarak kendi kendilerine hesap vermeli, öz değerlendirme yapmalıdırlar. Sonuncusu ise STK'ların kendileri ile benzer işi yapan diğer STK'lara hesap vermeleridir. Paydaş kuramına göre sürdürülebilir başarı elde etmek isteyen STK'lar paydaşların beklentilerini karşılamadır. Bir kuruluşun paydaşları ile ilişkilerini güçlendirmesi, paydaşlarını anlamaya çalışması ve onların beklentilerini karşılama çabası içerisinde olması o kuruluşa sorumlu yönetim, yenilikçilik, değişime uyum, sürdürülebilir finansal destek, kaynakların verimli kullanımı, misyona uygun faaliyetlerin gerçekleştirilmesi gibi yetkinlikleri kazandırmaktadır. Bu yetkinlikler ise STK'ların varlıklarını devam ettirmelerini sağlamaktadır.

Hesap verebilirlik kavramının gerekliliğini kuramsal bağlamda açıklayan bu yaklaşımlara ek olarak uygulamada STK'ları hesap verebilirliğe zorlayan çeşitli nedenler vardır. Bunları üç başlık altında toplamak mümkündür (Murtaza, 2012; McConvillea ve Corderyb, 2018; Rodriguez vd., 2012).

Birincisi STK'ların finansmanının doğrudan ya da dolaylı olarak toplum tarafindan yapılmasıdır. KUSİF'e göre (2017) Türkiye'deki durumda STK'ların finansman modelleri, kendini sürdürülebilir gelir getirici modellerden karma gelir modellerine ve yalnızca 
hayırseverliğe dayalı inisiyatifler tarafindan verilen bağışlara kadar değişim göstermektedir. Bununla birlikte başlıca gelir kaynakları önemli ölçüde üyelik aidatları ile bireylerin ve kurumların yaptığı bağışlardan oluşmaktadır (Çarkoğlu ve Aytaç, 2016; Kurt ve Taş, 2015). Bağışlar ve üye aidatları gibi iki temel finansman kalemi (Kurt ve Taş, 2015) doğrudan finansman aracı olarak kabul edilmektedir. Diğer taraftan kamu yararına faaliyet gösteren STK'lara yapılan bağışların, bağışçıların vergi matrahından indirilebilmesini mümkün kılan vergisel düzenlemeler, devletin tahsil edebileceği vergi gelirlerinin STK'larına aktarılması anlamına geldiğinden bu bağışların dolaylı finansman olarak değerlendirilmesi gerekmektedir. Finansmanı sağlayan toplum olduğundan, STK'ların faaliyetleri ve bunların finansal sonuçları hakkında toplumu bilgilendirmeleri gerekmektedir. Yalçın vd.'ye (2016) göre fon verenler doğrudan veya dolaylı olarak yaratılan değişimi anlamak, bilgi edinmek ve kaynaklardan en üst düzeyde yararlanıldığından emin olmak için STK'ların yürüttükleri faaliyetlerin etkileri hakkında bilgi sahibi olmayı istemektedir. Hatta STK'lara fon sağlayan kurumlar, STK'ların yaratmayı amaçladığı değişimlerin önceden saptanması, değişim alanlarına ilişkin göstergelerin belirlenmesi, ölçümleme ve değerlendirme yapılması gibi faaliyetleri içeren sosyal etki değerlendirmesinin yapılmasını beklemektedirler (Yalçın vd., 2016).

STK'ların faaliyetleri ve finansman sonuçları hakkında kamuoyunu bilgilendirmelerini gerektiren ikinci neden ise STK'larla ilgili olumsuz haberlerdir. STK'ların temel amac1 topluma hizmet ya da kamu yararı olmasına rağmen dönem dönem STK'ların adı ya da STK yöneticileri çeşitli yolsuzluk iddiaları ile anılmaktadır (Rodriguez vd., 2012:663). Ayrıca STK'ların terörün finansmanı, kara para aklama gibi yasa dışı işlerde kullanıldığı da görülmektedir (Murtaza, 2012). Ulusal ve/veya çokuluslu STK yöneticilerinin karıştığı iddia edilen yolsuzluk ve yasa dışı eylemlere ilişkin haberler, sadece habere konu olan STK'ları etkilememekte, diğer STK'ları da olumsuz etkileyerek bu kuruluşların meşruiyetlerine zarar vermektedir. Bu tür olaylardan ötürü STK'ların daha şeffaf olmasına yönelik güçlü bir talep söz konusudur.

Üçüncüsü STK'ların üstlendikleri misyon ve yarattıkları ekonomik katma değer ile sosyal ve ekonomik yaşamın oldukça önemli bir unsuru haline gelmiş olmalarıdır. Gelişmiş ülkelerin önemli göstergelerinden biri olan güçlü sivil toplum hareketlerinin oluşabilmesi güvene dayalı bir ortamın varlığına bağlıdır. $\mathrm{Bu}$ ortam için de sivil toplum paydaşlarının bilgilendirilmesi gerekmektedir. Çünkü sivil toplum hareketleri her ne kadar bünyesinde profesyonel çalışanlar istihdam etseler de özü itibarıyla gönüllülük esasına dayalıdır. Gönüllü katkı sağlayacak bireylerin ve kurumların ikna edilmesinde bilgilendirmeler önemli rol oynamaktadır. Buradaki temel amaç toplumsal güveni artırma yoluyla bağışçılığı yaygınlaştırmaktır. Toplumsal güveni sağlamak için STK'lardan muhasebe standartlarına göre hazırlanmış yıllık raporlar istenilmektedir (McConvillea ve Corderyb, 2018).

\section{TÜRKIYE'DE STK'LAR VE HESAP VEREBİLIRLIK}

Türkiye'de faaliyet gösteren STK'ların hesap verebilirliği yasal hesap verebilirlik ve gönüllü hesap verebilirlik olmak üzere iki bölümde incelenebilir. Yasal hesap verebilirlik kapsamı ve yöntemi yasalarla belirlenmiş denetim ve bildirim sorumluluğudur. Bazı STK'lar yasal düzenlemelerin ötesine geçmekte, küresel iyi uygulama örneklerinden esinlenerek faaliyetleri ve performansı hakkında daha detaylı raporlar hazırlamakta, bunları kamuoyu ile paylaşmaktadır. Bu durumu gönüllü hesap verebilirlik olarak tanımlamak mümkündür. 


\subsection{Yasal Hesap Verebilirlik}

Yasal hesap verebilirliğin kapsamı, yöntemi, verilecek beyannameler ve raporlama yapılacak merciler yasalarla düzenlenmiştir. Hesap verebilirlik hakkındaki düzenlemeler genellikle mevzuatın denetim, beyanname ve bildirim başlığı altında yer almaktadır. STK'larda iç ve dış denetim olmak üzere iki denetim sistemi bulunmakta ve denetim sonuçları farklı mercilere raporlanmaktadır. Yasal düzenlemelerde ilke olarak özdenetim öngörülmüş ve denetim işlevinin STK'ların yetkili kurulları olan denetim kurulu tarafından yapılması benimsenmiştir. Denetim kurulları yönetimi özellikle finansal yönden incelemekte ve bir rapor hazırlayarak tüm üyelerin katılabildiği genel kurula sunmaktadır. Dış denetimde bağımsız denetim kuruluşları ve kamu idarelerinden oluşan karma bir model bulunmaktadır. Ülkemizde STK'lar vakıf, dernek, sendika, siyasi parti ve meslek örgütü tüzel kişilikleri altında faaliyet göstermektedirler. Kuruluş, örgütlenme, yürütme, iç ve diş denetim, beyanname verme, tasfiye gibi konular yasalar ve yönetmeliklerle düzenlenmiş ve her bir STK grubu bir kamu idaresi ile ilişkilendirilmiştir. STK'lar ve kamu idareleri arasındaki ilişki hiyerarşik bir ast-üst ilişkisi şeklinde anlaşılmamalıdır. Tablo 1 Türkiye'deki STK gruplarını ve ilişkili kamu idaresini göstermektedir:

\section{Tablo 1. Sivil Toplum Kuruluşları ve İlișkili Kamu İdareleri}

\begin{tabular}{|c|c|c|}
\hline \multicolumn{2}{|c|}{ Sivil Toplum Kuruluşu } & İlgili Kamu İdaresi \\
\hline \multicolumn{2}{|l|}{ Vakıflar } & Kültür ve Turizm Bakanlığı Vakıflar Genel Müdürlüğü \\
\hline \multicolumn{2}{|l|}{ Dernekler } & $\begin{array}{l}\text { İçişleri Bakanlığı Sivil Toplum İlişskileri Genel } \\
\text { Müdürlüğ̈ü }\end{array}$ \\
\hline \multicolumn{2}{|c|}{ Sendikalar } & Aile, Çalışma ve Sosyal Hizmetler Bakanlığı \\
\hline \multicolumn{2}{|c|}{ Siyasi Partiler } & Anayasa Mahkemesi, Yargıtay Başsavcılığ \\
\hline \multirow{5}{*}{$\begin{array}{l}\text { Meslek } \\
\text { Örgütleri }\end{array}$} & $T \ddot{U} R M O B$ & Hazine ve Maliye Bakanlığ \\
\hline & $T M M O B$ & Çevre ve Şehircilik Bakanlığ \\
\hline & Türk Tabipleri Birliği & Sağlık Bakanlı̆̆ \\
\hline & Ticaret ve Sanayi Odalarl & Ticaret Bakanlığı \\
\hline & Barolar Birliği & Adalet Bakanlığı \\
\hline
\end{tabular}

Vakıflarda Denetim ve Bildirim Yükümlülükleri: Vakıf yönetimi; vakfın yönetici veya yönetim kurulu üyeleri listesini, bir önceki yıla ait faaliyet raporlarını, bütçe ve bilançolarını, gayrimenkullerini, malî tablolarını ve bu tabloların uygun araçlarla yayınlandığına dair belgeyi, işletme ve iştiraklerinin malî tabloları ile yönetmelikle belirlenecek diğer bilgileri içeren beyannameyi her takvim yılının ilk altı ayı içerisinde Genel Müdürlüğe verir. Mülhak, cemaat, esnaf vakıfları ile yeni vakıflarda iç denetim esastır. Vakıf; organları tarafından denetlenebileceği gibi, bağımsız denetim kuruluşlarına da denetim yaptırabilir. Vakıf yöneticileri, en az yılda bir defa yapılacak iç denetim raporları ile sonuçlarını, rapor tarihini takip eden iki ay içerisinde Genel Müdürlüğe bildirir. Vakıfların amaca ve yasalara uygunluk denetimi ile iktisadî işletmelerinin faaliyet ve mevzuata uygunluk denetimi Genel Müdürlükçe yapılır. ${ }^{1}$

\footnotetext{
${ }^{1}$ Vakıflar Kanunu (2008, 20 Şubat) Resmi Gazete (Sayı: 26800) http://www.mevzuat.gov.tr/MevzuatMetin/1.5.5737.pdf
} 
Derneklerde Denetim ve Bildirim Yükümlülükleri: Derneklerde iç denetim esastır. Genel kurul, yönetim kurulu veya denetim kurulu tarafından iç denetim yapılabileceği gibi, bağımsız denetim kuruluşlarına da denetim yaptırılabilir. Genel kurul, yönetim kurulu veya bağımsız denetim kuruluşlarınca denetim yapılmış olması, denetim kurulunun yükümlülüğünü ortadan kaldırmaz. Denetim kurulu; derneğin, tüzüğünde gösterilen amaç ve amacın gerçekleştirilmesi için sürdürüleceği belirtilen çalışma konuları doğrultusunda faaliyet gösterip göstermediğini, defter, hesap ve kayıtların mevzuata ve dernek tüzüğüne uygun olarak tutulup tutulmadığını, dernek tüzüğünde tespit edilen esas ve usullere göre ve bir yılı geçmeyen aralıklarla denetler ve denetim sonuçlarını bir rapor halinde yönetim kuruluna ve toplandığında genel kurula sunar. ${ }^{2}$

Dernekler, yılsonu itibarıyla faaliyetlerini, gelir ve gider işlemlerinin sonuçlarını düzenleyecekleri beyanname ile her yıl Nisan ayı sonuna kadar mülkî idare amirliğine vermekle yükümlüdürler. Toplam 12 bölümden oluşan bu beyannamede dernek yönetimi, organizasyon yapısı, uluslararası ilişkileri, çalışanları, iktisadi teşekkülleri, kısmen detaylı gelir ve gider tablosu, detaylı bilanço, yapılan ve alınan yardımlar ile sahip olunan varlıklar hakkında bilgi verilmektedir.

Sendikalarda Denetim ve Bildirim Yükümlülükleri: Sendikaların denetimi, kanun ve kuruluşun tüzük hükümlerine göre denetleme kurulları tarafından yapılır. Denetimde, yönetim ve işleyişin, gelir, gider ve bilançoların ve bunlarla ilgili işlemlerin kanun, tüzük ve genel kurul kararlarına uygunluğu incelenir. Kuruluşların gelir ve giderlerine ilişkin mali denetimleri, en geç iki yılda bir denetim yetkisine sahip yeminli mali müşavirlerce yapılır. Denetleme kurulu ve yeminli mali müşavirler tarafından hazırlanan denetim raporları sendika ve konfederasyonların genel kurullarına sunulur. Sendika ve konfederasyonların faaliyet, dış denetim ve denetleme kurulu raporları ile genel kurul kararları, genel kurul tarafindan belirlenen uygun vasitalarla derhal yayımlanır. Genel kurul kararlarıyla uygun vasitaların belirlenmediği durumlarda; faaliyet, dış denetim ve denetleme kurulu raporları ile genel kurul kararları, sendika ve konfederasyonların kurumsal resmi internet sitelerinin ana sayfasında veya ülke genelinde dağıtımı yapılan günlük bir gazetede derhal yayımlanır. ${ }^{3}$

Siyasi Partilerde Denetim ve Bildirim Yükümlülükleri: Siyasi partilerin mali denetimi Anayasa Mahkemesince yapılır. Anayasa Mahkemesi, siyasi partilerin mal edinimleri ile gelir ve giderlerinin kanuna uygunluğunu denetler. Siyasi partilerin genel başkanları, karara bağlanarak birleştirilmiş bulunan kesin hesap ile parti merkez ve bağlı ilçeleri de kapsayan iller teşkilatının kesin hesaplarının onaylı birer örneğini Haziran ayı sonuna kadar Anayasa Mahkemesine ve bilgi için Yargıtay Cumhuriyet Başsavcılığına vermek zorundadırlar. Bu belgelere, ilgili siyasi partinin aynı hesap döneminde edindiği taşınmaz ve değeri yüz milyon lirayı aşan taşınır malların, menkul kıymetlerin ve her türlü hakların değerleri ile edinim tarihlerini ve şekillerini de belirten listeleri eklenir. ${ }^{4}$

\footnotetext{
${ }^{2}$ Dernekler Kanunu, (2004, 11 Nisan) Resmi Gazete (Say1:25649) Erişim adresi: http://www.mevzuat.gov.tr/MevzuatMetin/1.5.5253.pdf

3 Sendika ve Konfederasyonların Denetim Esasları ve Tutacakları Defterler ile Toplu İş Sözleşmesi Sicili Hakkında Yönetmelik (2013, 26 Kasım) Resmi Gazete (Sayı:28833) Erişim adresi:

http://www.resmigazete.gov.tr/eskiler/2013/11/20131126-7.htm

${ }^{4}$ Siyasi Partiler Kanunu (1983, 22 Nisan), Resmi Gazete (Sayı: 18027): http://www.mevzuat.gov.tr/MevzuatMetin/1.5.2820.pdf 44
} 
Meslek Örgütlerinde Denetim ve Bildirim Yükümlülükleri: Meslek örgütlerinin denetim ve bildirim yükümlülükleri kendi özel kanunlarında münhasıran düzenlenmiştir. Meslek örgütlerinin mali denetimi ve faaliyet denetimi Tablo 1'de yer alan ilgili kamu idarelerince yapılmaktadır. Ayrıca meslek örgütleri yıllık finansal raporlarını belirli sürelerde ilgili kamu idaresine bildirmek zorundadırlar.

\subsection{Gönüllü Hesap Verebilirlik}

Gönüllü hesap verebilirlik, yasal bir zorunluluk olmamasına rağmen STK'ların faaliyetleri ve finansal durumları hakkında paydaşlarını ve kamuoyunu bilgilendirmeleridir. STK'ların konu olduğu yolsuzluk, kaynakların verimsiz kullanımı, israf, yasa dışı eylemlerde yer alma gibi olumsuz nitelikteki haberler bu kurumlara olan toplumsal desteği azaltmaktadır. Toplumsal destek sürdürülebilir başarı için ihtiyaç duyulan finansal bağışların sağlanması ve yurttaşların STK faaliyetlerine katılımı için gereklidir. Toplumsal desteği elde etmenin en önemli yollarından biri STK'lara olan güveni sağlamaktır. Faaliyetlerde ve finansmanda şeffaflık STK'lar hakkındaki soru işaretlerini ortadan kaldırarak, güven duygusunun pekişmesine yardımcı olmaktadır.

Gönüllü hesap verebilirlik konusunda fark yaratan kuruluşların internet sitelerini paydaşlarla iletişim bağlamında etkin bir şekilde kullanarak faaliyetlerde ve finansmanda şeffaflık çabası içerisinde oldukları görülmektedir. STK üst yönetimi ve kurulları hakkında tanıtıcı bilgiler, kilit personel iletişim bilgileri, organizasyon yapısı, şubeleri ve varsa uluslararası ilişkileri, kuruluşun geçmişte ve cari dönemde yer aldığı projeler, bu projelerin sorumluları, proje ortakları, proje kapsamında gerçekleştirilen faaliyetler hakkında bilgiler ile bülten, dönemsel faaliyet raporu gibi yayınlar faaliyet şeffaflı̆̆ına örnek olarak verilebilir. Diğer taraftan detaylı bir şekilde hazırlanmış ve kuruluşun geçmiş dönemlerine/cari dönemine ait bilanço ve gelir tablosu, ilişkili taraflarla yapılan işlemler, bütçe/performans değerlendirme gibi ek finansal tablolar, kuruluş tarafından ilgili kamu idarelerine verilen beyannamelerin birer kopyası, bağımsız denetimin yapılması, bağımsız denetim raporunun bir kopyasının paylaşılması, kuruluşun muhasebe yönergesinin paylaşılması finansal şeffaflık bağlamında gönüllü hesap verebilirlik iyi uygulama örnekleri olarak gösterilebilir.

\section{ABD'DE STK'LAR VE HESAP VEREBİLİRLIKK}

Çalışmanın bu bölümünde Amerika Birleşik Devletleri'ndeki (ABD) sivil toplum ortamı ve orada faaliyet gösteren STK'ların düzenli bir şekilde hazırladıkları, STK'ların hesap verebilirlikleri bağlamında iyi uygulama örneği olarak değerlendirilebilecek Form 990 beyannamesi hakkında özet bilgi verilmektedir.

\subsection{ABD'de Sivil Toplum Kuruluşları ve Vergisel Destekler}

ABD mevzuatında yardım dernekleri, sendikalar, ticaret odaları, siyasi partiler, kardeşlik örgütleri gibi kuruluşları kapsayan 30'dan fazla STK tanımlanmıştır. Bu STK'lar içerisindeki en büyük ve en etkili grubu vergi mevzuatında teknik bir sınıflandırma, Bölüm 501(c) (3), başlığı altında listelenen ve Türkçe'ye "yardım kurumları" olarak çevirebileceğimiz yardım dernekleri, dini örgütler, hastaneler ve eğitim kuruluşları oluşturmaktadır. Kayıtlı STK'ların üçte ikisi bu gruba girmektedir (McKeever, 2019; Fritz, 2019). Bu gruba giren kurumlar ya yardım kurumu (public charity) ya da vakıf (foundation) olarak sınıflandırılmaktadır. Yardım kurumları, gelirlerinin en az üçte birini toplumdan elde eden ve doğrudan faydalanıcılara hizmet veren kuruluşlardır. Vakıflar ise az sayıda ya da tek bir bağışçının desteği ile 
finansman sağlayan, kendisi doğrudan faaliyet gerçekleştirmeyip faaliyet gerçekleştiren diğer yardım kurumlarına bağışta bulunan kuruluşlardır (Sherlock ve Gravella, 2009). Yardım kuruluşlarına bağışta bulunan bireysel bağışçılar yaptıkları bağışları gelirlerinin \%50'sine kadar; kurumsal bağışçılar ise \%10'una kadar vergi matrahından indirebilmektedirler. Vakıflarda bireysel bağışçılar yaptıkları bağışları gelirlerinin \%30'una kadar vergi matrahından düşebilmektedirler ( $\mathrm{FG}$, tarih yok).

Vergisel avantajlardan faydalanabilmek için bağış yapılan STK'nın Amerika Gelir İdaresi Başkanlığınca (IRS) hazırlanan 501 (c) (3) listesinde yer alması gerekmektedir. Bu listeye girmek isteyen STK'lar IRS'e başvurmakta, listeye kabul edildikten sonra bu statülerini devam ettirebilmek için her mali yıl sonunda Form 990 adı verilen bir beyannameyi doldurmak zorundadırlar. $\mathrm{Bu}$ form ilgili kuruluş hakkında finansal ve örgütsel bilgiler içermektedir. Ross'a göre (2018) bu form STK'ların mali yapısı, gelir kaynakları gibi finansal konular hakkında detaylı bilgilerin yanısıra kamu idarelerine STK'larla ilgili yasal prosedürleri yönetebilmesi için ihtiyaç duyduğu diğer bilgileri de (vergi muafiyetini sürdürecek şekilde faaliyetler yürütülüp yürütülmediği, vergi muafiyetinin devam edip etmediği gibi) sağlamaktadır. Bunlara ek olarak Form 990'da bir STK'nın kurumsal yönetimine ve yürüttüğü programlarına ilişkin detaylı bilgiler de yer almaktadır (Moore, 2018).

Form 990 vergi muafiyeti tanınan STK'lar için en önemli finansal raporlama, pazarlama ve halkla ilişkiler aracı olarak görülmektedir (Gordon vd., 2007). Çünkü bu formlar STK'ların kendi internet sitelerinde ya da çeşitli araştırma sitelerinde yayınlanmaktadır. Böylelikle bağışçılar ve diğer paydaşlar formları inceleyebilmekte (Malamut ve Runquist, 2018) herhangi bir STK'nın bir mali yıl içerisindeki finansal bilgilerini, projelerini, faaliyetlerini, yönetimini detaylı bir şekilde gözden geçirerek (ILG, 2010) karar vermektedirler. Burada yer alan bilgiler yöneticilerin işlerin ne kadar iyi ya da başarılı yaptıklarının bir göstergesi olarak da kullanılmaktadır. Özellikle dikkatleri STK politikalarına ve uygulamalarına çekerek, bunların iyi yönetişim uygulamalarını dikkate alıp almadığını ortaya koymaktadır (Moore, 2018). Form 990 uygulamas1, bir bütün olarak, STK'lar üzerinde kamu denetimini gerçekleştirerek STK'ların varlık nedeninin kamusal fayda yaratmak olduğu gerçeğini başarılı bir şekilde yansıtmaktadır (ILG, 2010).

\subsection{Form 990: Biçim ve Bölüm İçerikleri}

İlk defa 1941 yılında iki sayfa olarak yayınlanan Form 990, üç evet/hayır sorusu, gelir tablosu ve bilançodan oluşmaktaydı. Zamanla geliştirilmiş ve son hali 2007 yılında düzenlenmiştir. Toplam kapak sayfası hariç 12 bölümden oluşan bu form finansal ve finansal olmayan kapsamlı bilgiler içermektedir (Gordon vd., 2007).

Kapak sayfası: Kurumun ismi, faaliyet alanı, iletişim bilgileri, adresi, organizasyon türü, vergi muafiyetinin olup olmadığı, vergi muafiyeti varsa türü gibi tanıtıcı bilgiler bulunmaktadır. Kapak sayfasında dikkat çekici bir şekilde bu belgenin kamu denetimine açık olduğu ifadesi yer almaktadır.

Bölüm 1: Bu bölümde toplam 22 madde yer almaktadır. Bu maddelerin 7 tanesi faaliyetler ve yönetim ile ilgili olup dördüncü bölümün özeti; 5 tanesi gelirlerin özeti; 7 tanesi harcamaların özeti ve üç tanesi ise net aktif özeti hakkındadır. 
Bölüm 2: İmza bölümüdür. STK yetkilisinin isim ve imza bölümünün yanısıra kurum dışından, ücret karşılığı hazırlayanlar için ayrı bir imza bölümü bulunmaktadır.

Bölüm 3: Bu bölümde STK'nın tamamlanmış projeleri hakkında detay bilgiler verilmektedir. İlk olarak kurumun misyonunu açıklanması istenilmektedir. Sonra cari dönemde sunulan ama önceki yıllarda verilen Form 990'larda yer almayan bir hizmet olup olmadığı bilgisi istenilmektedir. Daha sonra önceki dönemlerde verilen ama cari dönemde durdurulan ya da yapısı önemli ölçüde değiştirilen bir hizmet olup olmadığı sorulmaktadır. Son olarak cari dönemde gerçekleştirilen en büyük bütçeli üç projenin harcamalarına yer verilmesi istenilmektedir. Vergi muafiyeti tanınan STK'lar ek olarak topladıkları bağışları, elde ettikleri gelirleri ve harcamalarını sundukları proje bazında raporlamak zorundadırlar.

Bölüm 4: Dördüncü bölüm verilmesi gereken diğer beyannameler ya da belgelerin gözden geçirildiği bir kontrol listesi şeklinde tasarlanmıştır. Örneğin STK'nın vergi muafiyeti tanınan kurumlar listesinde yer alıp almadığı sorulmaktadır. Cevap evetse bu durumda Schedule A belgesinin doldurulması gerektiği ifade edilmektedir. Kontrol listesinde yer alan diğer bir maddede STK cari dönemde arazi ve arsa, bina, demirbaşlar gibi aktiflerinde bir artış olduğu raporlandıysa bu durumda Schedule $\mathrm{D}$ belgesinin yedinci bölümünü doldurulması gerektiği ifade edilmektedir. $\mathrm{Bu}$ bölümde toplamda 38 madde yer almakta, bağımsız denetim raporunun olduğu ve olmadığı durumlarda, raporun hazırlayan STK'nın bir okul olması ya da yurt dışında şubelerinin ve çalışanlarını olması durumunda ya da kurumun 25.000 dolardan fazla ayni bağış alması durumunda hangi formların doldurulması gerektiği bilgileri yer almaktadır. Böylelikle STK'ların faaliyetleri ile ilgili hazırlanması ve raporlanması gereken diğer formları kontrol edilebilmektedir.

Bölüm 5: Vergi İdaresi dosyaları ve vergi uyumu ile ilgili bildirimler yer almaktadır. Bu bölümde kurumca yürütülen faaliyetlerin vergi muafiyeti kapsamına girip girmediğini anlamaya yönelik sorular sorulmakta ve bazı durumlarda ek beyannameler ya da formlar istenilmektedir. Örneğin bir STK'nın cari dönemde yabancı ülkede herhangi bir finansal faaliyet yürütüp yürütmediği sorulmakta; cevabın evet olması durumunda kurumun FinCen Form 114 kodlu Yabancı Bankalar ve Muhasebe Hesapları başlıklı raporu hazırlaması gerektiği bilgisi yer almaktadır.

Bölüm 6: İdare organları, kurullar, üst yönetim, politikalar ve açıklamalar hakkındadır. Üç alt bölümden oluşmaktadır. Birinci alt bölümde idari organlarda yer alan üyelerin sayısı, üyeler arasında oy hakkı açısından önemli farkların olup olmadığı, yönetsel hakların belirli bir komiteye ya da üyeye önemli ölçüde devrinin olup olmadığı, kuruluş çalışanları, mütevelli heyet üyeleri ve kilit personel arasında akrabalık ilişkilerinin olup olmadığı, bir önceki raporlama döneminden bugüne yönetsel belgelerde önemli bir değişiklik olup olmadığı, kurul toplantılarının kayıt altına alınıp alınmadığı, bu bölümde listelenen kurul üyelerinin kurumsal mail adreslerinin olup olmadığ almaktadır. İkinci alt bölüm kuruluşta bazı politikaların var olup olmadığını sorgulamaktadır. Örneğin kuruluşun şubeleri ve yerel birimleri olup olmadığı, varsa bunların genel merkez ile uyumlu çalışmasını sağlayan/denetleyen politikaların olup olmadı̆̆ı, Form 990'nın kurul üyelerine sunulup sunulmadığı, kuruluşta yazılı bir çıkar çatışması politikası olup olmadığı, varsa bunun nasıl uygulandığı, kuruluşta yazılı bir içerden bilgi ile yolsuzlukların duyurulması (whistleblower) politikası olup olmadığı, kuruluşun yazılı belge saklama ve imha etme politikasının olup olmadığı gibi sorular yer almaktadır. Üçüncü alt bölüm açıklamalar hakkındadır. Doldurulan ve beyan edilen Form 990'nın kamuoyu erişimine nasıl 
sağlanacağı (kendi sitesinde yayınlamak, başka bir sitede yayınlamak, isteğe bağlı sunmak gibi), mali yıl içerisinde finansal tabloların, kurul kararlarının ve diğer yazılı politikaların kamuoyu ile paylaşılıp paylaşılmadığı, paylaşılıyorsa nasıl paylaşıldığı, muhasebe yetkilisinin isim, adres ve iletişim bilgisi istenilmektedir.

Bölüm 7: Memurlara, yöneticilere, mütevelli heyet üyelerine, kilit personele, en fazla ödeme yapılan çalışanlara ve dış tedarikçilere yönelik ödeme bilgilerinin açıklandığı bölümdür. İki alt bölümden oluşmaktadır. Alt bölümlerden birincisi kurum içi görevlilere yapılan ödemeler hakkında; ikinci alt bölüm ise dış tedarikçilere yapılan ödemeler hakkında bilgi sunmaktadır. Birinci alt bölümde ilk olarak, kuruluşta çalışan tüm memurların, yöneticilerin, bireysel ve kurumsal mütevellilerin ismen ve bunlara yapılan ödemelerin, miktarı ne olursa olsun, listelenmesi istenilmektedir. Daha sonra varsa kuruluşta çalışan kilit personelin ve yapılan ödemelerin listelenmesi istenilmektedir. İlk iki maddede listelenenler dişında kuruluşta çalışıp, kuruluştan ya da ilişkili kuruluşlarından toplamda 100.000 dolar üstünde ödeme alan ilk beş kişinin ismen açıklanması istenilmektedir. Ayrıca önceki dönemlerde kuruluşta memur, mütevelli, kilit personel ya da yönetici olarak çalışıp cari dönemde 100.000 dolar üstünde ödeme yapılması durumunda bunun da raporlanması gerekmektedir. İkinci alt bölümde cari dönemde kuruluştan 100.000 dolardan daha fazla ödeme alan diş tedarikçilerin isimleri ve ödeme tutarları raporlanmalıdır.

Bölüm 8: Gelirlerin detaylı bir şekilde açıklandığı bölümdür. Gelirler; kampanyalar, üyelik aidatları, etkinlik gelirleri, bağışlar, ilişkili taraflardan gelirler, devlet tahsisleri, hediyeler, diğer bağışlar, ayni bağışlar, program gelirleri, yatırım gelirleri (temettü, faiz vb.), telif gelirleri, kira gelirleri gibi detaylı bir şekilde raporlanmaktadır.

Bölüm 9: Giderlerin fonksiyon esasına göre detaylı bir şekilde açıklandığı bölümdür. Ulusal kurumlara ve bireylere yapılan bağışlar, uluslararası ölçekte bireylere ve kurumlara yapılan bağışlar, maaş ödemeleri, kıdem tazminatı karşılıkları, çalışanlara sağlanan diğer haklar, vergiler, maaş ödemeleri dışında kuruluşun gerçekleştirdiği faaliyetlere yönelik giderler (yönetsel, yasal, muhasebe, lobi, danışmanlık hizmetleri, yatırım danışmanlığı, reklam ve tanıtım, ofis, bilişim teknolojileri, telif ödemeleri, yazılım, kira, seyahat, konferans, sergi ve toplantı, faiz, amortisman ve diğer giderler) detaylı bir şekilde bu bölümde gösterilmektedir.

Bölüm 10: Bilanço bölümüdür. Muhasebe standartlarına uygun, kapsamlı, kuruluşun aktiflerini ve pasiflerini detaylı bir şekilde hazırlanmış finansal durum tablosu raporlanmaktadır.

Bölüm 11: Net aktif mutabakatı bölümüdür. Dönem başı net aktifler, dönem içi gelirler, dönem içi giderler, gelecek yıllara ait gelirler ile giderlerin ve önceki bölümlerde verilen seçilmiş bazı finansal bilgiler kullanılarak net varlıklardaki değişim mutabakatı yapılmaktadır.

Bölüm 12: Finansal tablolar ve raporlama bölümüdür. Kuruluşun hazırladığı ve yayınladığı finansal tabloların güvenilirliği/kalitesi hakkında ölçütler yer almaktadır. Bu çerçevede öncelikle kuruluşun son raporlama döneminden sonra muhasebe politikalarında bir değişiklik olup olmadığı, finansal tabloların bağımsız denetçi incelemesi olup olmadığı, finansal tabloların bağımsız denetiminin yapılıp yapılmadığı, kuruluşta denetim faaliyetlerini gözeten bir denetim komitesinin var olup olmadığı bu bölümde sorgulanmaktadır. Bu sorulara verilen olumlu cevapların finansal tabloların güvenilirliğini artıracağı ortadadır. 


\section{DEĞERLENDIRME VE ÖNERILER}

STK'larda hesap verebilirlik ve özellikle toplumu bilgilendirme kapsamında Türkiye'deki mevzuat ve ABD'de Form 990 uygulaması hakkında verilen bilgiler 1şı̆̆ında aşağıdaki değerlendirmeleri yapmak mümkündür:

Form 990 uygulaması Türkiye'deki uygulamalara kıyasla daha kapsamlıdır. Türkiye'de faaliyet gösteren STK'ların da hesap verebilirlik kapsamında çeşitli belgeler hazırlama zorunluluğu bulunmaktadır. Örneğin dernekler, her yıl dernekler beyannamesini vermekle; vakıflar ise vakıflar beyannamesini hazırlamakla mükelleftirler. Bu beyannameler Form 990'a göre daha dar kapsamlı tasarlanmıştır. Özellikle giderlerin sınıflandırılması ve çalışanlara yapılan ödemeler konusunda Form 990 daha detaylı bilgi sunmaktadır. Finansal bilgilerin daha kapsamlı verilmesi, giderlerin ve ödemelerin kamuya açılması STK'ları harcamalarında daha rasyonel davranmaya teşvik edecektir.

Hesap verilen merciler/yerler konusunda da iki ülke uygulamaları arasında oldukça önemli temel farklılık bulunmaktadır. Türkiye'de bildirimler çeşitli şekilde olabilmektedir. Örneğin genel kurullarda katılımcılara bilgi verilmesi, gazetelerde ilan edilmesi, genel kurulun ilan biçimine yetki vermesi ve çok nadiren internet sitelerinde ilan edilmesi gibi. Türkiye'de STK'ların hesap verebilirliğinin, esas denetleyicinin ilgili kamu idaresi olduğu bir model üzerine kurulduğunu söylemek yanlış olmayacaktır. ABD'de vergi muafiyeti tanınan STK'lar (çok büyük bir kısmı vergi muafiyetlerinden istifade etmektedir) kamu idarelerine ek olarak bu beyannamelerin tamamını internet sitelerinde ilan etmek zorundadırlar. Böylelikle bağışçılar ve diğer paydaşlar Amerika'daki herhangi bir STK'nın yöneticilerinin kim olduğu, misyonu, temel politikaları, projeleri gibi yönetsel bilgilerinin yanı sıra gelirlerinin ne kadar olduğu, hangi projelere ne kadar para harcadığı, yöneticilerinin ne kadar maaş aldığı gibi finansal bilgilerine de erişebilmektedir.

STK'ların finansal tablolarını internet sitelerinde paylaşmaları oldukça önemlidir. Çünkü finansal tabloları hazırlayanların kasten ya da hatayla yanlış finansal bilgiler sunması her zaman mümkündür. Gordon vd.(2007) ABD'de yaptıkları araştırmada STK'ların Form 990'da yer alan finansal bilgileri ile aynı STK'ları denetleyen bağımsız denetçilerin raporlarında yer alan bilgiler arasında önemli farklılıklar olduğunu ortaya çıkarmışlardır. Bu farklılıkları da internet sitelerinden topladıkları raporları karşılaştırarak belirleyebilmişlerdir. Kasıtlı ya da hatalı yanlış bilgilendirmelerin önlenebilmesi için hesap verebilirlik kapsamında hazırlanan raporların/beyannamelerin/bildirimlerin internette yayınlanması zorunlu olmalıdır. Türkiye'de de STK'ların bu belgeleri kendi internet sitelerinde yayınlamaları ya da ilgili kamu idarelerinin kendilerine sunulan bu bilgi ve belgeleri kendi internet sitelerinde yayınlamaları kamusal denetimi mümkün kılacaktır.

Türkiye'de STK türüne göre farklı kamu idarelerine raporlama zorunluluğu bulunmaktadır. Gelir İdaresi Başkanlığı ya da Sivil Toplumla İlişkiler Genel Müdürlüğü tarafindan hazırlanacak Form 990 benzeri kapsamlı bir beyanname ile bu raporlama sistemi tek merkezden yönetilebilir. Böylelikle dağınık bir görüntü veren STK'larda hesap verebilirlik alanı daha verimli çalıştırılabilir.

\section{SONUÇ}

Türkiye'de sivil toplum faaliyetleri son yıllarda önemli bir ivme kazanmış olsa da gelişmiş ülkelerle kıyaslandığında hâlâ istenilen seviyede olmadığı söylenebilir. STK'lara, 
faaliyetlerine, projelerine, yöneticilerine ve çalışanlarına duyulan güven bu kuruluşlara yönelik toplumsal desteği doğrudan etkilemektedir. Güveni sağlamanın en önemli yolu kuruluşların faaliyetleri ve finansal sonuçları hakkında paydaşları bilgilendirmesi, faaliyet ve finansman şeffaflığını sağlamasıdır. Şeffaflık STK'lar hakkındaki soru işaretlerini ortadan kaldırmanın yanında STK' larda iyi yönetişim uygulamalarının hayata geçmesine de yardımcı olmaktadir.

Türkiye'de faaliyet gösteren STK'lar ilgili kamu idarelerine ve kendi yetkili kurullarına sınırlı çerçevede raporlama yapmaktadırlar. Öncelikle bu raporların kapsamının genişletilmesi gerekmektedir. Özellikle gelirler ve giderlerin detaylı bir şekilde gösterilmesi, yöneticilere, çalışanlara ve tedarikçilere yapılan belirli bir tutarın üzerindeki ödemelerin raporlarda yer alması önemlidir. Diğer taraftan bu bilgilere bütün paydaşların erişimi sağlanmalıdır. Bunun en etkili yolu bu bilgilerin kuruluşun kendi internet sitesinde ya da bir kamu idaresinin internet sitesinde yayımlanmasıdır.

Hesap verebilirlik uygulamalarının geliştirilmesi STK'ları sorumlu yönetim anlayışı çerçevesinde kaynaklarını daha verimli kullanmaya zorlayacağı gibi STK'ların arkasındaki toplumsal desteği artırarak ülkemizde sivil toplumun büyümesine ve gelişmesine katkıda bulunacaktır.

\section{KAYNAKÇA}

ÇARKOĞLU, A. ve AYTAÇ, S.E. (2016). Türkiye'de Bireysel Bağışçıllık ve Hayırseverlik, İstanbul: TUSEV.

ÇELİK, N. ve BEDÜK, A. (2014). "Vekâlet Teorisi Yaklaşımı ile İşlem Maliyeti Arasındaki İlişki”. Sakarya İktisat Dergisi, 3(1): 43-67.

ÇINARLI, İ. (2014), “Stratejik İletişim Yönetimi Bağlamında Paydaş Kuramının Eleştirel Bir Değerlendirmesi”. İstanbul Üniversitesi İletişim Fakültesi Dergisi, 1(46): 23-36.

ERTUĞRUL, F. (2008). "Paydaş Teorisi ve İşletmelerin Paydaşları ile İlişkilerinin Yönetimi”. Erciyes Üniversitesi İktisadi ve İdari Bilimler Dergisi, (31): 199-223.

FG. (2019). What is a 501(c)(3)? Foundation Group: Erişim tarihi 15.02.2019, https://www.501c3.org/what-is-a-501c3/

FRITZ, J. (2019, 2 16). How the IRS Classifies Nonprofit Organizations. Small Business: https://www.thebalancesmb.com/how-the-irs-classifies-nonprofit-organizations2501798

GORDON, T., KHUMAWALA, S.B., KRAUT, M.A. ve MEADE, J.A. (2007). "The Quality and Reliability of Form 990 Data: Are Users being Mislead". Academy of Accounting and Financial Studies, 11: 27-79.

ILG (2010). Pondering Public/Nonprofit Collaborations: What a Form 990 Says about a Nonprofit. Institute for Local Government.

KEYMAN, F. (2006). Türkiye'de Sivil Toplumun Serüveni. İstanbul: Sivil Toplum Geliştirme Merkezi.

KURT, S. ve TAŞ, H.Y. (2015). “Toplum Örgütlerinde Profesyonel ve Gönüllü Çalışma İlişkileri: Tehditler ve Fırsatlar”. Uluslararası Emek ve Toplum Dergisi, 4(8): 199-214. 
KUSİF (2017). Sosyal Finansman Rehberi, Koç Üniversitesi Sosyal Etki Forumu Yayınları, İstanbul

LEE, J. (2004). NGO Accountability: Rights and Responsibilities. Genneva: CASIN.

LLOYD, R. (2005). The Role of NGO Self-Regulation in Increasing Stakeholder Accountability. London: One World Trust.

MALAMUT, M.E. ve RUNQUIST, L.A. (2018). Governance Challenges for Nonprofits Posed by the New IRS http://apps.americanbar.org/buslaw/newsletter/0074/materials/pp2.pdf

McCONVILLEA, D. ve CORDERYB, C. (2018). “Charity performance reporting, regulatory approaches and standard-setting". Journal of Accounting and Public Policy, (37): 300314.

McKEEVER, B.S. (2019). The Nonprofit Sector in Brief 2018: Public Charites, Giving, and Volunteering. Urban Institute: Erişim tarihi, 16.02.2019, https://nccs.urban.org/publication/nonprofit-sector-brief-2018\#the-nonprofit-sector-inbrief-2018-public-charites-giving-and-volunteering

MİRZ, K. ve ÜLGEN, H. (2013). İşletmelerde Stratejik Yönetim. İstanbul: Beta Yayınları.

MOORE, J. (2018). James Moore. James Moore Certified Public Accountans and Auditors: https://www.jmco.com/how-to-review-the-form-990/

MURTAZA, N. (2012). "Putting the Lasts First: The Case for Community-Focused and PeerManaged NGO Accountability Mechanisms". VOLUNTAS: International Journal of Voluntary and Nonprofit Organizations, 23: 109-125.

RODRIGUEZ, M.d., PEREZ, M.d., ve GODOY, M. (2012). "Determining Factors in Online Transparency of NGOs: A Spanish Case Study”. Voluntas: 661-683.

ROSS, S. (2018). Examining Page One of the Form 990. https://www.kahnlitwin.com/blogs/mission-matters-blog/examining-page-one-of-theform-990

SHERLOCK, M.F. ve GRAVELLA, J.G. (2009). An Overview of the Nonprofit and Charitable Sector. Congressional Research Service.

ŞAHIN, L. ve ÖZTÜRK, M. (2008). "Küreselleşme Sürecinde Sivil Toplum Kuruluşları ve Türkiye'deki Durumu”. Sosyal Siyaset Konferansları Dergisi: (54), 3-29.

Vakıflar Yönetmeliği (2008, 27 Eylül), Resmi Gazete.

YALÇIN, A.S., EMİROĞLU, T. ve GÜNER, D. (2016). Fon Veren Kurumlar İçin Sosyal Etki Ölçümleme Rehberi, İstanbul: Koç Üniversitesi Sosyal Etki Forumu.

YUESTI, A., NOVITASARI, L. ve RUSTIARINI, N. (2016). "Accountability of NonGovernment Organization from the Perspective of Stakeholder Theory”. International Journal of Accounting and Taxation, 4(2): 98-119. 